\title{
Latvijas diplomāti par mūsu ārpolitikas simtgadi
}

Recenzija par grāmatu: Mārtiņš Drēğeris (sast.). Latvijas diplomātijas gadsimts. Latvijas diplomātijas un ārlietu dienesta pirmais gadsimts (1919-2019) diplomātu esejās. Rīga 2020. 606 Ipp. ISBN 978-9934-0-8820-9

Jānis Taurēns

LATSUAS DIPLOMITIJAS UN ARLIETC DIENEST PIRMAIS GADSIMTS (1919-2019) DIPLOJIITU ESEJT̃

Aizvadītā Latvijas neatkarības simtgade radīja pašsaprotamu vēlmi atskatīties uz simts gados paveikto. Ārpolitika vienmēr bijusi nesaraujami saistīta ar Latvijas Republikas likteni laiku lokos. Ne vienmēr mūsu tautai ir izdevies lemt savu likteni pašai, tomēr nu jau vairāk nekā puse gadsimta ir aizvadīta neatkarības apstāklıs.

2020. gadā nāca klajā diplomāta un jurista Mārtina Drēgéra iniciētā un sastādītā 606 lappuses biezā grāmata "Latvijas diplomātijas gadsimts", tā sastāv no M. Drēgera priekšvārda un 26 nodaḷām, kuras drīzāk būtu jāsauc par rakstiem vai, kā izvēlējušies teikt paši autori, - par esejām. Grāmatā ievietoti vairāki vēsturiski pārskati par 
ārpolitikas norisēm pagātnē un diplomātu esejas par valsts mūsdienu ārpolitikas problēmjautājumiem. İsā ievadā ārlietu ministrs Edgars Rinkēvičs īpaši uzsver, ka Latvijas ārpolitiskās koncepcijas pamatā jābūt orientācijai uz Rietumiem: "Latvijai skaidri un neapšaubāmi jāpozicionējas kā Rietumu civilizācijas sastāvdalıi" (17. lpp.).

Grāmatā ievietota arī hronoloǵiska tabula par galvenajiem notikumiem Latvijas ārpolitikā, to sastādījuši Valdis Rūsiņš un Gints Apals. Diemžēl 30 gadus ilgajam periodam kopš neatkarības atjaunošanas veltītas tikai nepilnas trīs lappuses, un, piemēram, laikā no 2008. līdz 2013. gadam nav noticis gluži nekas ievērības cienīgs, lai gan tas neliekas pamatoti.

Pie vēsturiskajiem pārskatiem jāmin Ginta Apala raksts par valsts ārpolitiku starpkaru periodā, Argitas Daudzes pārskats par Latvijas diplomātisko dienestu okupācijas periodā un paša M. Drēgera apcerējums par personībām Latvijas ārlietu dienestā. Grāmata iepriecina vēsturnieka sirdi arī tajā ziṇā, ka vairākkārt uzsver Latvijas Universitātes Vēstures un filozofijas fakultātes mācībspēku un studentu devumu Latvijas ārlietu dienestam pēc neatkarības atjaunošanas (Alberts Sarkanis 147. lpp. un Mārtiņš Drēgeris 535 lpp.). Vispārinot varētu teikt, ka Latvijas ārpolitika un vēsture ir cieši saistītas gan filozofiskā, gan konkrētu personību līmenī. Protams, šī nav vienīgā Ārlietu ministrijas sagatavotā grāmata. Īpaši jāatzīmē diplomātu eseju (atmiṇu) krājums, kas iznāca pirms dažiem gadiem. $^{1}$

Uzmanību piesaista G. Apala pārskats par valsts ārpolitiku pirms Otrā pasaules kara. Autors ḷoti kritiski vērtē valsts ārpolitiku kara priekšvakarā, norādot uz Baltijas Antantes vājumu un nespēju izškirīịi rīkoties kritiskajā pirmskara situācijā. Arī Baltijas valstu neitralitātes politiku G. Apals pamatoti vērtē kā neadekvātu. Vai Latvijai bija kāda ārpolitiska alternatīva
1939.-1940. gada trag̣ēdijai? Katrā gadījumā tā nebija meklējama Krievijā. "Nepietiekama izpratne par komunistiskā režìma totalitāro raksturu deva pamatu ilūzijām par iespēju saglabāt" ierobežotu neatkarību vai zināmu autonomiju (61. lpp.). Vēstures literatūrā ir spilgti izteikts uzskats: "Lai kādi arī nebūtu bijuši Latvijas ārpolitikas un diplomātijas trūkumi vai stiprās puses, diplomātiskā cel̦ā Latvijas drošỉba vispār nebija nodrošināma."

Vēstniece Argita Daudze pievērsusies Latvijas diplomātijas un trimdas organizāciju darbībai okupācijas periodā. Vina atzīmējusi šo diplomātu un organizāciju lomu Baltijā, īpaši uzsverot ASV nostāju, gan būdama pietiekami kritiska pret Rietumu politiku. A. Daudze atzīmē, ka šis periods prasīja "gan pacietibu, gan elastibu no baltiešiem, lai [...] uzturētu spēkā prasību par okupācijas izbeigšanu" (82. lpp.). Mārtinsš Drēgéris apṇēmies portretēt personības Latvijas diplomātiskā dienesta vēsturē. Protams, gan 1919., gan 1991. gadā bija līdzīgas problēmas - Ārlietu ministrija bija jāveido no jauna. Abos gadījumos liela loma bija humanitāro zinātṇu speciālistiem (502., 535. lpp.), un abos gadījumos sākumā trūka atbilstoša atalgojuma. Interesants aspekts esejā ir diplomāšu lomas atspogul,ojums ārpolitiskajā dienestā. Esejā plaši aplūkota atsevišķu diplomātu darbība, reizēm pat pārāk plaši, piemēram, Miķel̦a Valtera ieguldījums apskatīts no 508. līdz 512. lappusei, savukārt, rakstot par mūsdienu diplomātiem, tekstā dominē plašs personu uzskaitījums bez izvērstāka apskata, kas droši vien pamatoti atstāts tagadnes un nākotnes vēsturniekiem.

Apcerējumiem par Latvijas mūsdienu ārpolitiku ir l,oti prominenti autori. Publicistiskajā literatūrā atzīmēta vairāku grāmatas autoru svarīgā loma Latvijas eiroatlantiskajā integrācijā, piemēram, gatavojot NATO samitu. ${ }^{3}$ Vairākiem autoriem ir nenovērtējama nozīme Latvijas neatkarības 
atjaunošanā, tās starptautiskajā atzīšanā un ārlietu dienesta izveidē.

Autoru vidū ir trīs ārlietu ministri (Sandra Kalniete, Māris Riekstiņš un Edgars Rinkēvičs), daudzi vēstnieki un citi ietekmīgi diplomāti. Šo rakstu tematika skar galvenos ārpolitikas virzienus, piemēram, Latvijas integrāciju Eiropas Savienībā (Eduards Stiprais, 185.-208. lpp.), attiecības ar ASV (Ilgvars Kḷava, 241.-268. 1pp.) un attiecības ar Krieviju (Gunda Reire, 287.-306. lpp.).

Ilgvara Kḷavas rakstā par attiecībām ar ASV ir vairāki konceptuāli interesanti aspekti, piemēram, viņš uzsver, ka Latvijas ārpolitika 90. gados bija "stingri sakṇota reālismā”, ko noteica valsts vēsturiskā pieredze, Krievijas armijas izvešanas procesa pieredze, ǵeopolitiskā situācija. Latviju nevarēja glābt "ANO vai EDSO vai Eiropas Padome" (250. lpp.), bet droša izvēle bija tikai "pievienošanās NATO militārajai aliansei, kurā ASV spēlē vadošu lomu" (251. lpp.). Kopumā autors augstu vērtē ASV nozìmi Latvijas drošības nostiprināšanā, norādot uz konkrētiem lēmumiem NATO paplašināšanās procesā 90. gados. No raksta uzzinām, ka īsu brīdi pēc "Krievijas militārās agresijas" sākuma pret Ukrainu ASV gaisa spēku elementi dažu stundu laikā tika pārvietoti atbilstoši jaunajai situācijai (264. lpp.). I. Kḷava tomēr kritiski vērtē atslābumu, kas iestājās Latvijas ārpolitikā pēc uzṇemšanas NATO. Pazīmes, kas liecināja par nepatīkamām pārmaiṇām jau kopš Krievijas un Gruzijas kara 2008. gadā, netika pienācīgi novērtētas.

Gunda Reire analizējusi Latvijas un Krievijas attiecību dinamiku. Izejas punkts, no kura būtu jāsāk Krievijas politikas analīze, pētniecei ir atziṇa, ka Krievijas cel̦š balstīts "uz padomju sentimentu, piepilditu ar imperiālistisku garu un mērḳi atgūt savu superlielvaras statusu, ideologisko dominanci un kontroli ārpus valsts robežām". Savukārt Latvijas uzdevumi ir sarežgīti, tiem raksturīga gan "ciña pret Krievijas ǵeopolitisko ietekmi, gan vēlme veidot noturïgas diplomātiskas attiecỉbas" (290. lpp.).

Šo rindu autoram, savukārt, šḳiet, ka abas vēlmes nav savietojamas, Krievija nepiekritīs "normāli tirgoties", atsakoties no politiskām interesēm un prasībām. Pat pirmskara periodā PSRS ekonomiskā politika pret Latviju bija tikai tās politiskās spēles sastāvdaḷa. ${ }^{4}$ G. Reire norāda, ka Krievijas lēmumiem ekonomiskajā jomā ir "politisks un stratēgisks raksturs" (293. lpp.). Tādos apstākḷıs arī rūpīgi gatavotajām Valsts prezidentu vizītēm Maskavā 2005. un 2010. gadā nebija raksturīgi ekonomiski un politiski ieguvumi. Runājot par nākotni un kopumā, autore secina, ka arī Rietumi ir dzīvojuši zināmā pašapmānā attiecībās ar Krieviju, būdami nepamatoti optimistiski par nākotni (303. lpp.).

Vēstnieks Eduards Stiprais nodaḷā par Eiropas integrāciju atzīmēe, ka tas bijis viņa dzīves lielākais piedzīvojums. Arī viņš noraida citas iespējamās ārpolitiskās izvēles kā nepamatotas, kaut arī Baltijas valstis tika uzskatītas par otrškirīgām salīdzinājumā ar Centrāleiropas valstīm un tās nebija "lielvalstu politikas radaros" (185.-187. lpp.). Tomēr Latvijas ārpolitikas konsekventais kurss, kuram izdevās radīt zināmu iekšpolitisku konsensu un kuru spēcīgi atbalstīja Ziemel̦valstis, nozīmēja lūzumu un pakāpeniskus panākumus. Iestāšanās sarunas Eiropas Savienībā bija nopietns pārbaudījums ārpolitiskā dienesta kapacitātei (kompetence, svešvalodu zināšanas, Eiropas tiesību integrācija), kā arī visas valsts pārvaldes kapacitātei. Zināma nozìme bija arī geopolitiskajiem aspektiem, lai gan to loma varēja būt pat lielāka, kā piesardzīgi atzīst E. Stiprais.

Vairākas esejas veltītas mazāk zināmiem jautājumiem. Ingrīda Levrence raksta par attiecībām ar jaunajām neatkarīgajām valstīm, kas izveidojās pēc PSRS sabrukuma, un Kinnas Tautas Republiku 
(307.-326. lpp.). Varbūt šāds tvērums ir pārāk plašs, n,emot vērā Ķīnas milzīgo nozīmi mūsdienu pasaules politikā. Sandra Kalniete pievērsusies neatkarības starptautiskās atzīšanas unikālajam procesam (101.-115. lpp.), konstatējot, ka tā sauktās lienošās atzišanas process bija unikāls diplomātijas vēsturē. Mārtinš̌ Virsis, rakstot par neatkarības atjaunošanas diplomātiskajiem aspektiem, norāda, ka starptautiskās tiesības, uz kurām balstījās Baltijas valstu neatkarības atjaunošana, ir atkarīgas no valstu "gatavïbas un apñēmības [...] tās aizstāvēt un istenot dzìve" (124. lpp.). Šì principa izpratne kḷuva ippaši svarīga neatkarības atjaunošanas periodā, un par to nevajadzētu aizmirst arī tagad.

Daudzām esejām pievienots literatūras saraksts vai atsauces, kas arī liecina par grāmatas vērtību. Pats par sevi saprotams, ka tās kḷūs par Latvijas diplomātijas vēstures avotiem, kas atspogul,o ne tikai faktus, bet arī konceptuālu izpratni par Latvijas ārpolitikas problēmām. Rezumējot jāatzīmē, ka Ârlietu ministrijas publicistisko darbību būtu vērts turpināt.

\section{ATSAUCES UN SKAIDROJUMI}

${ }^{1}$ KRISTĪNE KOZlOVA (sast.). Atgriešanās Eiropā Latvijas prezidentu, premjerministru, ministru un diplomātu esejās: no starptautiskās atzīšanas līdz pirmajai prezidentūrai Eiropas Savienībā, 1990-2015. Rīga 2016. Pieejams: https://dom.lndb.lv/data/obj/file/305363

${ }^{2}$ Aivars StrangA. Latvijas - padomju Krievijas miera līgums 1920. gada 11. augustā: Latvijas padomju Krievijas attiecības 1919.-1925. gadā. Rīga 2000, 227. lpp.

${ }^{3}$ Sanita Jemberga, Pauls Raudseps, Gunta Sloga. VVF. Prezidentes Vairas Vīkses-Freibergas politiskā biogrāfija. Rīga 2008, 164. lpp.

${ }^{4}$ StRANGA, Latvijas - padomju Krievijas miera līgums 1920. gada 11. augustā, 216.-224. lpp. et al. 